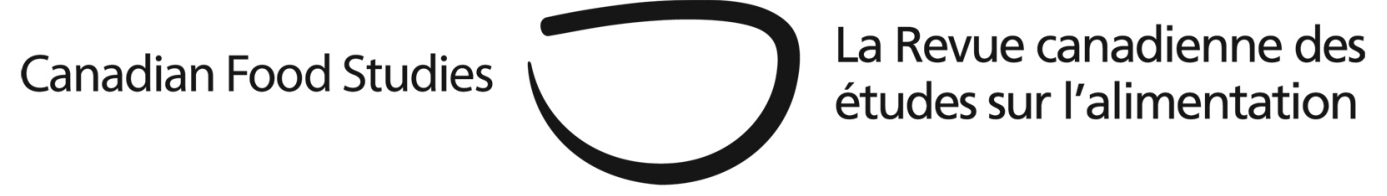

Section VII

Land grabs and agrarian reform

Special Issue: Mapping the Global Food Landscape

\title{
Land grabs, the agrarian question and the corporate food regime
}

\author{
A. Haroon Akram-Lodhi \\ Professor, Department of International Development Studies, Trent University
}

Over the last decade civil society organizations and activist-scholars have pointed to "land grabbing” as one of the central issues to have emerged in the world food system. In particular, land grabbing was identified as a new and immediate international development issue by the non-governmental organization GRAIN in 2008 (www.farmlandgrab.org). Since that time land grabbing has generated a voluminous literature of a highly variable quality-some scholarship is outstanding and some is shoddy (Oya, 2013). This contribution seeks to clarify what constitutes land grabbing and why it takes place, as well as the key challenge that scholars and civil society activists face in confronting land grabbing in the context of the question of feeding the world. The central argument is that when a structuralist political economy is used to interpret the land grab phenomenon, it becomes analytically clear that contemporary land deals demonstrate that dispossession by displacement, or what has historically been known as the "so-called primitive accumulation”, has been resurrected as an accumulation strategy of global capitalism witnessing, for the first time in decades, the limits to the market. It is an accumulation strategy that cannot, however, deliver food justice or deal with the climate emergency.

Land grabbing: What and why?

Land grabbing can be defined as the large-scale acquisition through buying, leasing or otherwise accessing productively used or potentially arable farmland by investors, that are most commonly 
corporations operating with state support, to produce food and non-food crops, to either boost supply for domestic and/or world markets or obtain a favourable financial return on an investment (Akram-Lodhi, 2012, p. 125). Large-scale refers to acquisitions of minimally 200 hectares, although such a cut-off point is quite relative-200 hectares of irrigated land in Southeast Asia is significantly different to 200 hectares of arid land in the Horn of Africa. Note as well that this definition includes, for reasons that will be discussed below, transactions of private property that are freely entered into between buyers and sellers on land markets. Corporate investors acquiring farmland may be the representatives of states, state-owned enterprises, or private capital, and they may be involved in agriculture, industry, or finance.

The scale of corporate farmland acquisition is extremely contentious and any claims that are made about it are derived from a weak evidentiary base (Cotula et al., 2014). So, when the International Land Coalition (ILC) produced a landmark 2012 report that found that between 2000 and 20112042 deals covering 203.4 million hectares were "reported as approved or under negotiation", this should be treated very carefully. So too should the claim that 1,155 deals covering 70.9 million hectares had been cross referenced from multiple sources as "actually already subject to acquisition” (Anseeuw et al., 2012, p.19). Moreover, while it is reasonably clear that land deals in Sub-Saharan Africa account for the largest share of land grabs, when the ILC suggests that Sub-Saharan Africa accounted for almost 50 percent of the global acreage involved and Asia covered around 20 percent of the total area involved, this claim too must be cautiously evaluated (Anseeuw et al., 2012).

The ILC study strongly argued that biofuels, food, and cash crops were important drivers of global farmland acquisition. However, the rise of fracking, particularly in North America, has resulted in a significant expansion of domestic energy supplies in many countries, resulting in downward pressures on energy prices, which has important implications for the viability of biofuel-driven land grabs and may explain multiple reports of failed land grab projects around biofuels (see, for example, Wise, 2014). In this light, it is probable that export-oriented food and cash crops are important drivers of the corporate farmland acquisitions continuing to take place. To this, however, finance should also be added, as will be discussed below (Breger Bush, 2012).

Land grabbing, market imperatives and the agrarian question

Ostensibly, the reason for large-scale corporate farmland acquisition was the increase in global food prices that commenced in 2007-08 (Akram-Lodhi, 2012). However, conjunctural events can also reveal more deep-seated processes, and this is the case with land grabbing: large-scale corporate farmland acquisition must be located within the ongoing development of capitalism in agriculture on a world scale. This is because land acquisition to increase the scale and scope of farming, either as a result of dispossession by outright politically-driven displacement - that is, the so-called "primitive accumulation"; or dispossession through accumulation - that is, marketled exclusion - is a routine and predictable part of the process of capitalist development (Akram- 
Lodhi, 2007; see also Hall, 2013). As capitalism reconfigures farming systems in order to increase the production of the marketed surpluses of food and cash crops that are necessary to sustain low-priced wage goods and industrial inputs and thus boost the profitability of capital, there is a need to increase the scale of production in order to better meet market imperatives. Market imperatives are defined as the need in commodity economies to sell farm output at competitive market prices by continually lowering costs of production by investing in costreducing techniques and technologies (Wood, 2008). This process results in increases in the scale of production, which take the form of an increase in the capital-intensity of farming systems, and thus an increase in the ratio of capital stock to land. The livelihood outcomes of this process are, for many in the countryside, negative, as market imperatives and profitability requirements undermine the capacities of many small-scale farmers to compete on domestic markets, and hence survive as viable farm operations. In so doing, an increase in the ratio of capital stock to land is consistent with increases in land holdings; indeed, capturing scale economies from farm equipment and machinery may require larger farms (World Bank, 2007). So land acquisition by emerging and/or established capitalist actors in agriculture, industry with a stake in farm production, or finance tied to agriculture, is wholly consistent with the problematic of the "agrarian question": whether, and, if so, how, capital is transforming farming and agricultural production systems. Capital transforms farming by enforcing market imperatives on farmers once their products become produced for the purpose of sale rather than use. In doing so it facilitates the emergence of capitalist relations of production, in which the means of production are under the control of a socially-dominant hegemonic class, labour is "free" from significant shares of the means of production and free to sell its capacity to work, and the purpose of commodity production is the seeking of profit (Akram-Lodhi \& Kay, 2010a).

In this light, a structural political economy would identify contemporary corporate farmland acquisition on a global scale as a form of counter-agrarian reform that must be situated within the logic of the agrarian question. This is because large-scale corporate farmland acquisition would be part of a process by which capital resolves the question of the role of agriculture in global accumulation by facilitating the establishment of large-scale, large-size farm units organized under increasingly capitalist relations of production. Note that these transactions can be of private property that is freely entered into between buyers and sellers on land markets. However, the extent of the "freedom" to enter into or exit from a transaction can be so severely circumscribed by the market imperative, and particularly by the accrual of debt as a result of the market imperative (Graeber, 2011), as to render the idea of freedom a fiction. At the same time, as capitalism transcends state boundaries the terms and conditions by which capital transforms farming and agriculture is subject to huge variation. This variation can be seen in terms of the social relations within which capital insinuates itself, the spatial landscapes over which capital operates, and the temporal frame in which processes of agrarian change are played out (Brent, this issue). As a consequence, the overarching structure that has to be understood if the process and implications of corporate farmland acquisition are to be fully grasped must be that of the dominant food regime, which can be used to situate the agrarian question within its world- 
historical context (McMichael, 2012). In a classic formulation, a food regime can be defined as the "international relations of food production and consumption" that can be directly linked "to forms of accumulation" (Friedmann \& McMichael, 1989, p. 95). It is now increasingly widely argued that the current food regime can be characterized as being corporate (Akram-Lodhi, 2012; Holt-Giménez \& Shattuck, 2011; McMichael, 2012).

\section{Land grabbing and the corporate food regime}

The corporate food regime is dominated by global agro-food transnational corporations, driven by financial market imperatives of short-run profitability, and characterized by the relentless food commodification processes that underpin "supermarketization". This regime forges global animal protein commodity chains while at the same time spreading transgenic organisms, which together broaden and deepen the temperate "industrial grain-oilseed-livestock" agro-food complex (Weis, 2013; Weis this volume). At the point of agricultural production, the dominant producer model of the corporate food regime is the fossil-fuel driven, large-scale, capitalintensive industrial agriculture megafarm, which in turn requires deepening the simple reproduction squeeze facing small-scale peasant petty commodity producers around the world and increasing the ranks of the relative surplus population (Akram-Lodhi \& Kay, 2010b). A core market for the agro-food transnational corporations of the corporate food regime are relatively affluent global consumers in the North and South, whose food preferences in the last quarter century have been shifted towards "healthier", "organic" and "green" products that have large profit margins. At the same time, though, for the global middle class the corporate food regime sustains the mass production of very durable highly processed food manufactures that are heavily reliant on soya, high fructose corn syrup, and sodium and whose lower profit margins mean that significantly higher volumes of product must be shifted. Thus, the corporate food regime simultaneously fosters the ongoing diffusion of industrial agriculture-Fordist food such as MacDonalds — as well as standardized differentiation — post Fordist food such as sushi (AkramLodhi, 2013). The corporate food regime is sustained by capitalist states, the international financial and development organizations that govern the global economy, and the big philanthropy that can sustain the expansion of capitalism (Fridell \& Konings, 2013). Notably missing from the profit-driven logic of the corporate food regime, however, are those that lack the money needed to access commodified food in markets and who are thus bypassed by the regime. This is the relative surplus population that is denied entitlements to food as a result of the normal and routine working of the global food system and who are thus subject to food-based social exclusion (Akram-Lodhi \& Kay, 2010b). For this relative surplus population the only answer to the global agrarian crisis lies in waged labour, whether it be on the farms of others that have successfully navigated the complex dynamics necessary for success in the corporate food regime, or whether it be off-farm, in rural or urban waged labour. 
Nonetheless, understanding the role of land grabs in the corporate food regime and both the specific land allocation and production processes at work and the outcomes is very difficult because of the fractional interests that are involved. Agribusiness capital seeks out land to grow food crops. Industrial capital seeks out land for cash crops and, probably now to a lesser extent, biofuels. Finance capital is interested in developing new crop- or land-based financial instruments, that could be tied to land deals and/or used for speculative gain. Moreover, different fractions of finance capital view land in different ways: speculators have different interests from hedge funds, for example. These distinctions have an important implication: while capital drives the direction by which land use does or does not change and in so doing directs an effective counter-reform in land- and agrarian-based social relations in support of industrial agriculture megafarms, different fractions of capital have quite different objectives that govern their behaviour. Agribusiness and industrial capital both seek to produce more so that rising demand for food, feed, fibre and, perhaps, fuel can be matched by an increasing physical supply of food and non-food agricultural crops. Finance capital wants less to be produced so that scarcity drives prices upwards and in so doing increases the possibility of arbitrage-based profit.

Having said that, as land grabs facilitate an increase in large-scale, capital-intensive industrial agricultural megafarms at the expense of small-scale petty commodity peasant producers an "extensification of intensification" takes place that is most reminiscent of the socalled "primitive accumulation". This is because it is predicated upon the dispossession of smallscale petty commodity peasant producers, not through the normal workings of highly imperfect markets capable of being shaped by social power, but rather through outright extra-economic imperatives as local and national states promote and facilitate the enclosure of lands that they claim are empty. Thus, land grabs foster, in effect, not agrarian reform but counter-reform in the countryside as land holdings concentrate and centralize. In an age of chronic economic crisis, contemporary land deals demonstrate that dispossession by displacement has been resurrected as an accumulation strategy of global capitalism witnessing, for the first time in decades, the limits to the market as a result of the global economic crisis that started in 2007 (Kaufman, 2012). Of course, the implications of this profitability strategy for the expanding ranks of an insecure relative surplus population and those most directly impacted by a systemic global subsistence crisis are not considered because of the food-based social exclusion that is a defining characteristic of the corporate food regime.

\section{Land grabbing and feeding the world}

As has already been stressed, it is clear that even after more than five years of intensive research on the processes and implications of land grabs, the state of knowledge is actually very limited. This is to be expected given the narrow time horizon within which scholars and civil society organizations have worked. In this light, it is not possible to make definitive statements about the 
scale, scope, processes, and outcomes of land grabs. While intuitive insights are possible, there is nonetheless a significant "known unknown" at work: significantly more evidence is needed.

Having said that, the fundamental question facing scholars, civil society activists, and policy makers is not so much about land grabs as about the form of agriculture they facilitate. Land grabs, through the extensification of intensification, facilitate the further development of large-scale capital-intensive industrial agriculture (Li, 2011). This begs a central question: are capital-intensive industrialized agricultural megafarms an agrarian production form capable of feeding the world in 2050? More research that investigates the following questions is needed: how extensive is large-scale corporate farmland acquisition, nationally, regionally and globally? To what extent does large-scale corporate farmland acquisition result in the creation of "extractivist" farms that treat food production as just another commodity, like oil and gold, to be mined from the land until land is exhausted, with implications for biodiversity and sustainability (Brent this volume)? Indeed, as finance becomes interested in land, food, and agriculture, but treats it simply as a new kind of asset class that can drive increased financial profits, what are the implications for the food system of the ongoing enclosures of land, intellectual property and other forms of commons (Akram-Lodhi, 2007)? And what is the impact of large-scale corporate farmland acquisition on the living standards of local communities over time?

It is increasingly apparent that large-scale capital-intensive industrialized agricultural megafarms are in the process of reaching their ecological limits and in so doing will restrict the development of the forces of production in agriculture. This is witnessed in the contribution of industrial agriculture to global warming, in the systemic inefficiencies of an extractive model of agriculture that depletes soil minerals and micronutrients, and in the health crisis that is a direct consequence of the corporate food regime (Akram-Lodhi, 2013, forthcoming). The continued development of productive forces in a way that not only feeds the world but also cools the planet, while providing viable livelihoods, requires an alternative agricultural production model that can continue to increase farm productivity and the production of marketable surpluses. That model is likely to be a significantly scaled up version of agroecology, given its potential to transcend the limits to accumulation inherent in the corporate food regime by facilitating the ongoing development of the productive forces (see Ahmed, Snipstal, and Zerbe, this issue; see also Chappell, 2007).

However, in order to facilitate an agroecological transition that resolves the agrarian question within the context of a new food regime, certain preconditions are required (AkramLodhi, forthcoming). For example, among others, there is a need for pro-poor, gender-responsive agrarian reform; restrictions on the operation of land markets in order to sustain the position of smallholders; increasing agricultural surpluses through sustainable biotechnological change; a reconstruction of local food systems rooted in the landscapes within which they are embedded and which can shape tastes, as was historically the case; the reconstruction of the public sphere as the first step in contesting the state in order to facilitate the emergence of a pro-poor, genderresponsive state; and restrictions on the operation of global food markets through the creation of an International Trading Organization that would be designed to manage food supplies in order 
to enhance human development, full employment, and sustained increases in the standards of living of the marginalized.

Clearly, this is an ambitious agenda. It is not something that will be given, as it fundamentally challenges the patterns of economic power and privilege that shape our times (Piketty, 2014). It can only come about if, as Eric Holt-Giménez (2011) stresses, food sovereignty movements seeking social transformation reshape the "common sense" of other, progressive and reformist, elements of global food movements that have different and contrasting ideological perspectives on capitalist development and thus different agendas. Transformational food sovereignty movements must seek to inclusively find common ground with progressive and reformist food movements in order to construct a new form of food hegemony rooted in a socially-just and climate-friendly agroecology.

\section{Questions for future research}

1. How extensive is large-scale corporate farmland acquisition, nationally, regionally and globally?

2. Are "extractivist” capital-intensive industrialized agricultural megafarms sustainable in the period to 2050 ?

3. Does the financialization of the food system produce ongoing enclosures of diverse forms of commons around the world?

4. What is the impact of large-scale corporate farmland acquisition on the living standards of local communities over time?

\section{References}

Akram-Lodhi, A.H. (2007). Land, markets and neoliberal enclosure: An agrarian political economy perspective. Third World Quarterly, 28(8), 1437-1456.

Akram-Lodhi, A.H. (2012). Contextualizing land grabbing: Contemporary land deals, the global subsistence crisis and the world food system. Canadian Journal of Development Studies, 33(2), 119-142.

Akram-Lodhi, A.H. (2013). Hungry for change: Farmers, food justice and the agrarian question. Halifax and Winnipeg: Fernwood Books. 
Akram-Lodhi, A.H. (forthcoming). Accelerating towards food sovereignty. Third World Quarterly.

Akram-Lodhi, A.H., \& Kay, C. (2010a). Surveying the agrarian question (part 1): Unearthing foundations, exploring diversity. Journal of Peasant Studies, 37(1), 177-202.

Akram-Lodhi, A.H., \& Kay, C. (2010b). Surveying the agrarian question (part 2): Current debates and beyond. Journal of Peasant Studies, 37(2), 255 - 284.

Anseeuw, W., Wily, L.A., Cotula, L., \& Taylor, M. (2012). Land rights and the rush for land: Findings of the global commercial pressures on land project. Rome: International Land Coalition. Retrieved from http://www.landcoalition.org/sites/default/files/publication/1205/ILC\%20GSR\%20report_ ENG.pdf

Breger Bush, S. (2012). Derivatives and development: A political economy of global finance, farming and poverty. New York: Palgrave MacMillan.

Chappell, M.J. (2007). Shattering myths: Can sustainable agriculture feed the world?. Food First Backgrounder, 13(3). Retrieved from http://foodfirst.org/wpcontent/uploads/2013/12/BK13_3-Shattering-Myths-Agroecology-2007.pdf

Cotula, L., Oya, C., Codjoe, E.A., Eid, A., Kakraba-Ampeh, M., Keeley, J., ... Rizzo, M. (2014). Testing claims about large land deals in Africa: Findings from a multi-country study. Journal of Development Studies, 50(7), 903-925.

Fridell, G., \& Konings, M. (eds). (2013). Age of icons: Exploring philanthrocapitalism in the contemporary world. Toronto: University of Toronto Press.

Friedmann, H., \& McMichael, P. (1989). Agriculture and the state system: The rise and fall of national agricultures 1870 to the present. Sociologia Ruralis, 29(2), 93-117.

Graeber, D. (2011). Debt: The first 5,000 years. Brooklyn, NY: Melville House Publishing.

Hall, D. (2013). Primitive accumulation, accumulation by dispossession and the global land grab. Third World Quarterly, 34(9), 1582-1604.

Holt-Giménez, E. (ed). (2011). Food movements unite! Strategies to transform our food systems. Oakland, CA: Food First Books. 
Holt-Giménez, E., \& Shattuck, A. (2011). Food crises, food regimes and food movements: Rumblings of reform or tides of transformation? Journal of Peasant Studies, 38(1), $109-144$.

Li, T. M. (2011). Centering labor in the land grab debate. Journal of Peasant Studies, 38(2), 281-298.

Kaufman, F. (2012). Bet the farm: How food stopped being food. Hoboken, NJ: John Wiley and Sons.

McMichael, P. (2012). The land grab and corporate food regime restructuring. Journal of Peasant Studies, 39(3-4), 681-701.

Oya, C. (2013). Methodological reflections on land "grab" databases and the land "grab" literature “rush”. Journal of Peasant Studies, 40(3), 503-520.

Piketty, T. (2014). Capital in the $21^{\text {st }}$ century. Cambridge, MA: The Belknap Press.

Weis, T. (2013). The ecological hoofprint: The global burden of industrial livestock. London: Zed.

Wise, T. (2014, June 27). Picking up the pieces from a failed land grab project in Tanzania. Global Post. Retrieved from http://www.globalpost.com/dispatches/globalpostblogs/rights/picking-the-pieces-failed-land-grab-project-tanzania

Wood, E.M. (2008). Peasants and the market imperative: The origins of capitalism. In A.H. Akram-Lodhi \& C. Kay (Eds.), Peasants and globalization: Political economy, rural transformation and the agrarian question. London: Routledge.

World Bank. (2007). World development report 2008: Agriculture for development. New York: Oxford University Press. 